\title{
Preliminary River Morphometry Analysis for Rafting Tourism in the Saba River, Bali Island, Indonesia
}

\author{
Slamet Suprayogi ${ }^{1}$, Bachtiar W. Mutaqin ${ }^{1,2}$, Yuli Widyaningsih ${ }^{3}$, Galih Dwi Jayanto ${ }^{3}$, Muh Rizali Umarella ${ }^{4}$, Muh Aris \\ Marfai $^{1^{*}}$ \\ ${ }^{1}$ Department of Environmental Geography, Faculty of Geography, Universitas Gadjah Mada, Yogyakarta 55281, Indonesia \\ ${ }^{2}$ Laboratoire de Géographie Physique, UMR 8591, Université Paris 1 Panthéon Sorbonne, Paris 92190, France \\ ${ }^{3}$ Master Program on Coastal Area and Watershed Planning and Management, Faculty of Geography, Universitas Gadjah Mada, \\ Yogyakarta 55281, Indonesia \\ ${ }^{4}$ Doctoral Program of Geography, Faculty of Geography, Universitas Gadjah Mada, Yogyakarta 55281, Indonesia
}

Corresponding Author Email: arismarfai@ugm.ac.id

https://doi.org/10.18280/ijsdp.150505

Received: 14 April 2020

Accepted: 8 June 2020

\section{Keywords:}

whitewater rafting, morphometry, mapping, management, risk, tourism, Bali, Indonesia

\begin{abstract}
This study was designed to calculate the morphometry along the SWISS rafting route, as well as map the whitewater and analyze the risk management of the rafting tourism at the Saba River in Buleleng Regency, Bali, Indonesia. The whitewater mapping was conducted using a river morphometry analysis, and the morphometry data was collected using field measurements, topographics, and a geographic information systems vector analysis. The river morphometry, which plays an important role in the rafting sport, was quantified using the spatial aspects, topography, length of the main river, and river flow. The results showed that the river had a slope of $14.2 \mathrm{~m} / \mathrm{km}$, a dam-regulated flow rate of up to $4.02 \mathrm{~m}^{3} / \mathrm{s}$, and water levels of $0.4-0.7 \mathrm{~m}$. These figures indicate that the river channel and its hydrological characteristics are suitable for rafting activities, and it has been categorized as grade 2-3 rapids. Due to the improper risk management of whitewater rafting, this research recommends improving the skills of the tour guides or the members of the local tourism awareness group and preparing emergency response strategies that consider the site's accessibility and the available medical services.
\end{abstract}

\section{INTRODUCTION}

Ecosystems provide several benefits for humans, such as scenic beauty and recreational activities [1-4]. As an ecosystem that shares the same benefits [5], many rivers have been developed into tourist attractions, including rafting. Whitewater rafting is a natural attraction that stimulates adrenaline. According to the Indonesian Rafting Federation (FAJI), rafting is an activity that involves navigating rivers using either rubber boats or something similar, which is steered by a crew of two or more people who rely on the power of rowing. The rafting was first introduced in Indonesia in 1970 and has been recognized as a sports activity since 1975 . In 1994, the first National Rafting Championship was held in Ubud, Bali. Sobek Expedition first commercialized the rafting, and it continues to grow in popularity in Indonesia [6].

Rafting is nature-based tourism; therefore, it depends on the natural or morphometric conditions, especially of the river. The flow discharge, width, slope, and turbulence of the river are the main morphometric factors [7] that affect the formation of whitewater, both directly and indirectly $[6,8]$. For example, the ideal river slope for whitewater rafting is $10-20 \mathrm{~m} / \mathrm{km}$ [6]. A more complex morphometry analysis for the river tourism attraction has been conducted using the following parameters: stream order, stream length, mean stream length (Lsm), stream length ratio (RL), bifurcation ratio $(\mathrm{Rb})$, drainage density $(\mathrm{Dd})$, drainage frequency $(\mathrm{Fs})$, texture ratio $(\mathrm{T})$, form factor (Rf), circularity ratio (RC), maximum basin length ( $\mathrm{Lg})$, constant of channel maintenance $(\mathrm{C})$, relief ratio $(\mathrm{Rh})$, and ruggedness number (RN) [9].

Furthermore, the riverbed roughness determines the emergence of turbulence, while the cross-sectional width controls the lateral distribution of the river flow discharge. An analysis is used for a broader perspective to determine the route of water tourism by assessing the availability of the water quantity, as well as the measurements related to the possibility of navigational techniques [10]. In addition, the watercourse incline is a factor in determining the speed and considering the difficulty by looking at the river sinuosity. Although this research uses parameters that are not as complex as the previous studies [9, 10], this research is considered a pioneer, as it provides new insight and understanding of the use of morphometric data, topography, and its integration with spatial analysis in a geographic information systems (GIS) vector environment.

Since safety is an unavoidable factor that must be considered during the development of rafting tourism, the river flood hazard analysis is essential. Flooding is a threat to whitewater rafting; in response to this, morphometry data can help to predict the river flood discharge [11-13]. The flood pattern is illustrated by a graph that shows the relation between the flow discharge and time and is called the flood hydrograph. It represents the product of the interaction between the climate and the physiographical condition of the river [14]. 


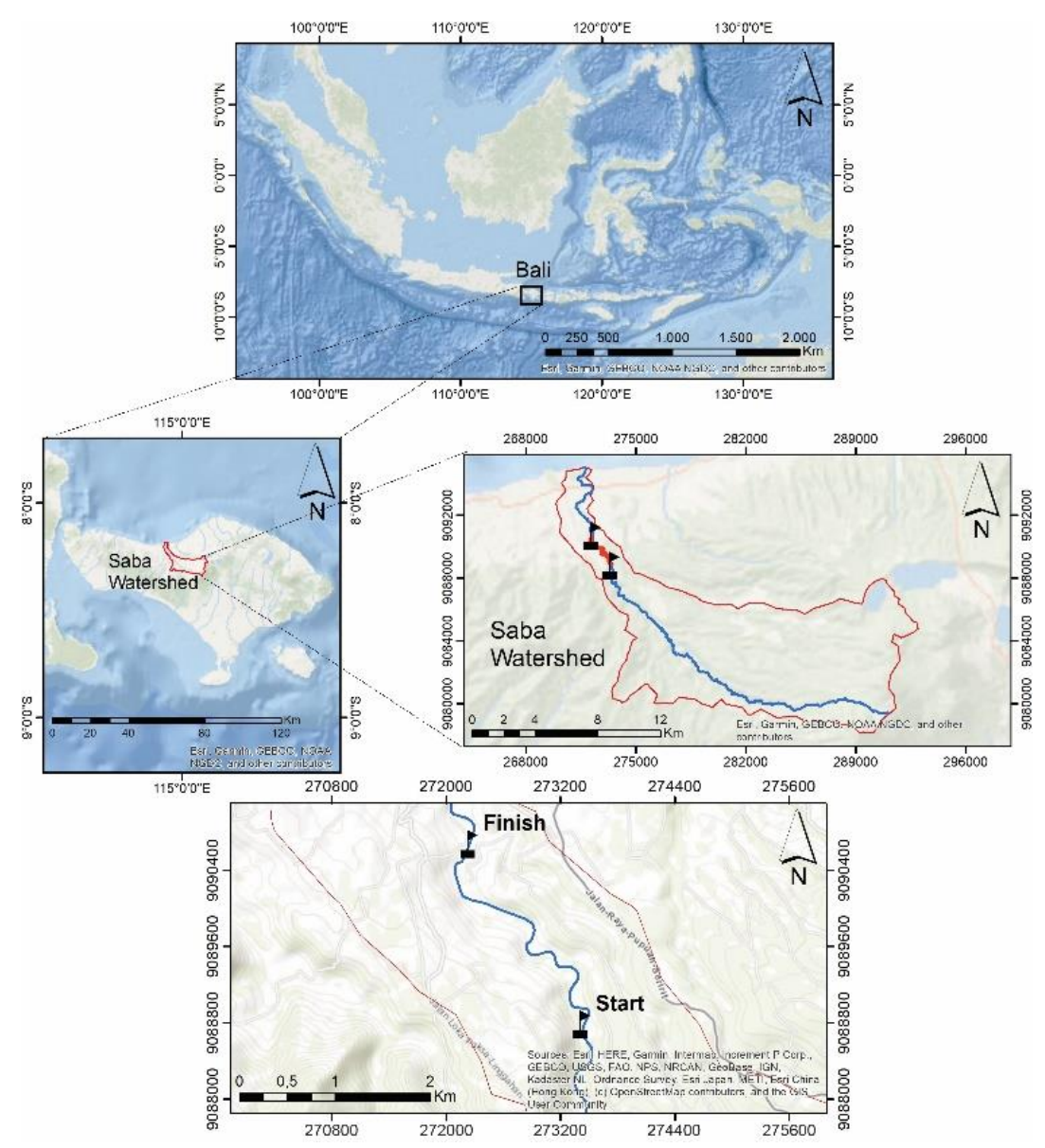

Figure 1. The research location in the Saba Watershed, Bali

The Saba watershed is in the Buleleng Regency in Bali Island, Indonesia. It covers a catchment area of $145.55 \mathrm{~km}^{2}$ with the main river stretching along $35.73 \mathrm{~km}$; therefore, it is categorized as a small watershed [15]. These conditions support the development of rafting tourism on this river. The Rafting Tourism Route on the Saba River, which is known as Route SWISS, was developed in 2017. In an attempt to support its sustainable development, a morphometric analysis has been carried out on several segments of the river. Morphometry analysis of the Saba River is essential to study its hydrological conditions, as it is a consideration when planning and implementing tourism and risk management. This study has been designed to quantitatively characterize the morphometry of the Saba River, map the whitewater, and analyze the risk management of rafting tourism in the Saba River (Figure 1)

\section{METHODS}

This research begins with building a digital elevation model (DEM) from satellite imagery of ALOS PALSAR, which is guided by the Indonesian topographic map in a GIS vector environment. The use of GIS technology here will help to conduct a spatial analysis. The next step is the identification and measurements of the flow discharges and velocity measurements, both of which are key factors in rafting sports, followed by field observations and measurements. Detailed portraits of the condition of the channel, identification of rapids, sinuosity, obstacles, and rock distributions were carried out during the field measurements. These results were used for the channel analysis and risk factors for the rafting route. The method that is depicted in Figure 2 provides a summary.

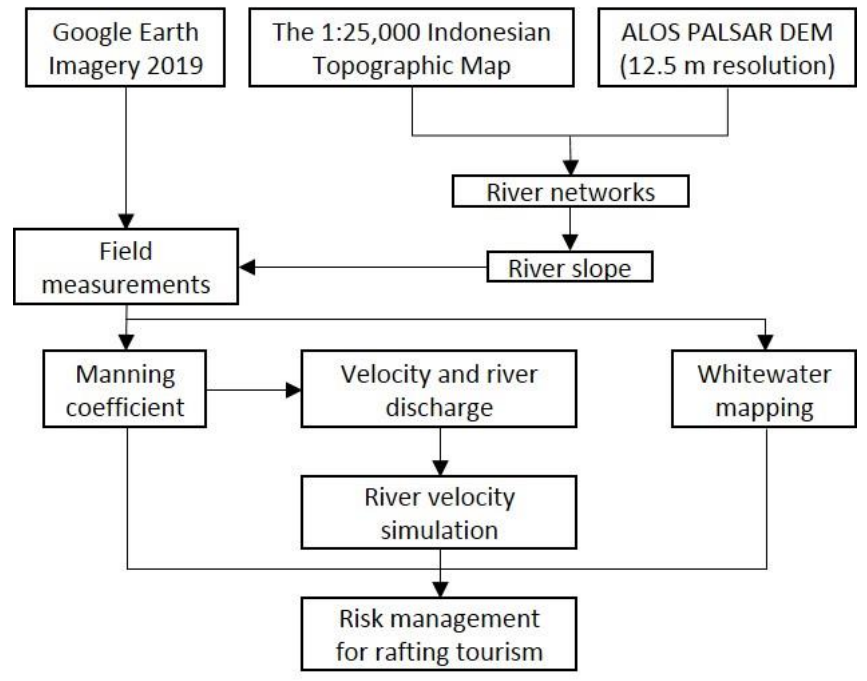

Figure 2. The research flowchart

\subsection{Characteristics of the Saba River Channel}

The risk management study of the whitewater rafting tourism uses DEM, which is derived from ALOS PALSAR with a resolution of $12.5 \mathrm{~m}$, and the 2017 Indonesian topographic map (scale 1: 25.000). The integration of the remote sensing technique and the topographic map gives this research an advantage compared to previous studies from [79]. The integration of detailed data from ALOS PALSAR, which has a good resolution and is guided by the topographic map, leads to a detailed DEM for a further analysis, such as to discover the topographic and morphometry of the study area. 
The DEM data has been built through a GIS vector environment using ArcGIS software and functioned from the line interpolation system of the counter from the topographic map. The altitude information from the ALOS PALSAR data is combined with the altitude data from a 1: 25.000 scale topographic map to produce a new DEM, and the visualization of the DEM data uses the hillshade formulation in ArcMap 10.3. The hillshade formulation uses the neighborhood approach of each cell value. The DEM (Figure 3 ) will guide the description of the morphometry condition, route identification, and access point to determine the start and endpoints.

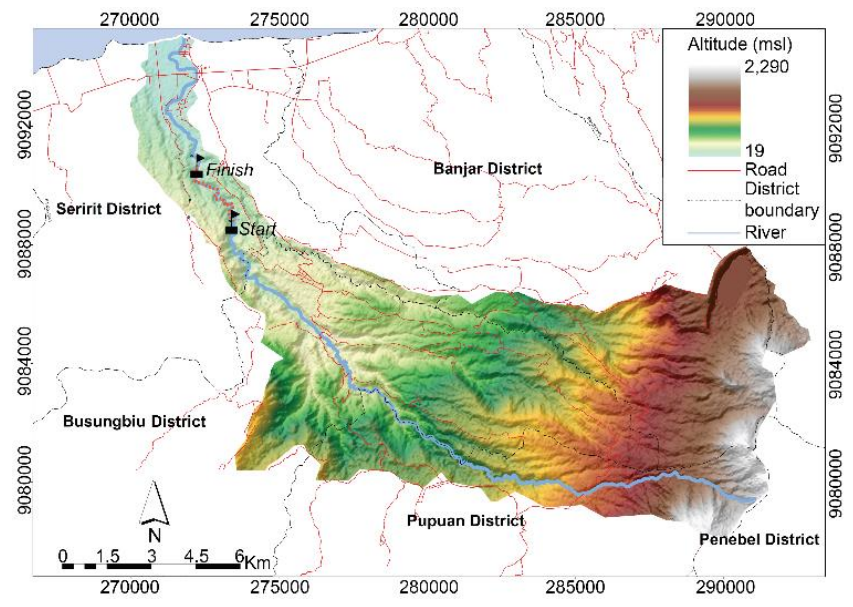

Figure 3. The DEM data in the Saba Watershed, Bali

Table 1. Manning's roughness coefficients [20]

\begin{tabular}{|c|c|c|c|}
\hline \multicolumn{2}{|c|}{ Channel Conditions } & \multicolumn{2}{|c|}{$n$-values } \\
\hline \multirow{4}{*}{ Bed materials } & Earth & \multirow{4}{*}{$\mathrm{n}_{0}$} & 0.020 \\
\hline & Rock cuts & & 0.025 \\
\hline & Fine gravel & & 0.024 \\
\hline & Coarse gravel & & 0.028 \\
\hline \multirow{4}{*}{$\begin{array}{l}\text { Degree of channel } \\
\text { irregularity }\end{array}$} & Smooth & \multirow{4}{*}{$\mathrm{n}_{1}$} & 0.000 \\
\hline & Minor & & 0.005 \\
\hline & Moderate & & 0.010 \\
\hline & Severe & & 0.020 \\
\hline \multirow{3}{*}{$\begin{array}{l}\text { Variations of } \\
\text { channel cross- } \\
\text { section }\end{array}$} & Gradual & \multirow{3}{*}{$\mathrm{n}_{2}$} & 0.000 \\
\hline & $\begin{array}{l}\text { Alternating } \\
\text { occasionally }\end{array}$ & & 0.005 \\
\hline & $\begin{array}{l}\text { Alternating } \\
\text { frequently }\end{array}$ & & $0.010-0.015$ \\
\hline \multirow{4}{*}{$\begin{array}{c}\text { The relative effect } \\
\text { of structures and } \\
\text { narrowing }\end{array}$} & Negligible & \multirow{4}{*}{$\mathrm{n}_{3}$} & 0.000 \\
\hline & Minor & & $0.010-0.015$ \\
\hline & Appreciable & & $0.020-0.030$ \\
\hline & Severe & & $0.040-0.060$ \\
\hline \multirow{4}{*}{ Vegetation } & Low & \multirow{4}{*}{$\mathrm{n}_{4}$} & $0.005-0.010$ \\
\hline & Medium & & $0.010-0.025$ \\
\hline & High & & $0.025-0.050$ \\
\hline & Very high & & $0.050-0.100$ \\
\hline \multirow{3}{*}{$\begin{array}{l}\text { Degree of } \\
\text { meandering }\end{array}$} & Low & \multirow{3}{*}{$\mathrm{n}_{5}$} & 1.000 \\
\hline & Appreciable & & 1.150 \\
\hline & Severe & & 1.300 \\
\hline
\end{tabular}

This topographic map provides information about the river networks, elevations, and land use. Furthermore, a GIS analysis was used to support the approach in disaster mitigation planning. The DEM is the primary source of the data that is derived from satellite imagery, which, in this study, provides information on the morphometry of the Saba River. In the case of rafting, the contributing morphometric parameters specifically refer to the characteristics of the river channel. The parameters that were measured in the study include the river slope, meandering aspects, river width, and riverbed roughness. The DEM data was integrated with the GIS analysis and field surveys to quantify the morphometric parameters [16-19]. The channel characteristics were determined based on Manning's roughness coefficient, which was developed by Chow [20] and is shown in Table 1.

\subsection{Flow discharge and velocity measurement}

The velocity-area method was employed to measure the river flow discharge and velocity. This technique estimates the flow velocity (V) and wet cross-sectional area (A) $[21,22]$. The flow velocity was calculated based on the constant of the current meter that was used during the field measurements, whereas the wet cross-sectional area was determined using the principle of the mean-section method. The mean-section method considers the average depth to obtain the wet crosssectional area of the channel. The discharge measurement is illustrated in Figure 4.

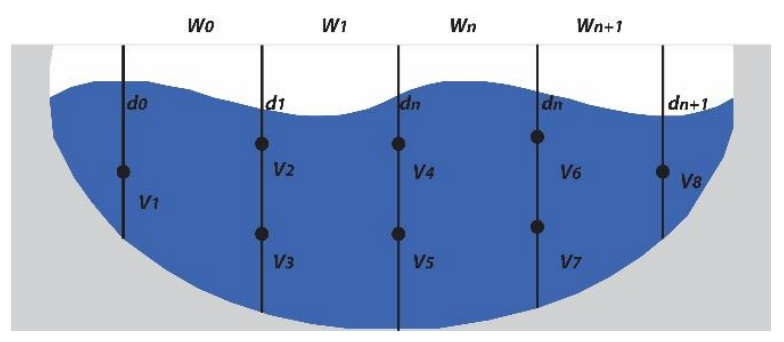

Figure 4. Profile of the cross-sectional area measurement using the mean-section method [21]

Afterward, the discharge of the channel was computed using the Eqns. (1), (2), and (3) below:

$$
\begin{gathered}
\mathrm{Q}=\mathrm{A} * \mathrm{~V} \\
\mathrm{~V}=\mathrm{a}+\mathrm{b} \\
\mathrm{A}=\left(\frac{d 0+d 1}{2} x w 0\right)+\cdots+\left(\frac{d n+d(n+1)}{2} \times w n\right)
\end{gathered}
$$

\subsection{Simulation of the river flow velocity}

The river flow velocity was simulated through the slope area method. This approach estimates the maximum discharge [23, 24] and incorporates the parameters that were used in the estimation to describe the characteristics of the channel based on Manning's roughness coefficient. The equations that were used to calculate the flow velocity are Eqns. (4), (5), and (6), as follows:

$$
\begin{gathered}
\mathrm{Q}=\mathrm{A}^{*} \mathrm{~V} \\
\mathrm{~V}=(1 / n) R^{2 / 3} S^{1 / 2} \\
\mathrm{~A}=\left(\mathrm{n}_{0}+\mathrm{n}_{1}+\mathrm{n}_{2}+\mathrm{n}_{3}+\mathrm{n}_{4}\right) \mathrm{m}
\end{gathered}
$$

\subsection{Whitewater mapping and field survey}

The whitewater on the Saba River was mapped by walking along Route SWISS. This trail has been planned for a future rafting tourism site. The first condition to consider when determining whether a stretch of river is suitable for rafting is 
the slope. Route SWISS has a slope of $10-20 \mathrm{~m} / \mathrm{km}$, which is ideal for rafting. The whitewater features were identified through professional judgment and mapped using a global positioning system (GPS). During the walks, the physical appearances of the river and any potential rafting obstacles were documented to provide an overview of the overall condition of the rafting route.

\section{RESULTS}

Whitewater rafting is included in the category of naturebased tourism, ecotourism, and adventure tourism (NEAT). NEAT is tourism that is based on the diversity of the attractions that are offered by nature [25]. In the case of the Saba River, the types of attractions are the whitewater features that are spread out along the rafting route. The starting point of the whitewater rafting route is located nine to $12 \mathrm{~km}( \pm 30$ minutes) from downtown Seririt District or $30 \mathrm{~km}$ ( \pm one hour) from the capital of Buleleng Regency, Singaraja City. From the topographic analysis, the starting point is located on the elevation of $129 \mathrm{~m}$ above mean sea level (AMSL) with $2.5 \mathrm{~m}$ of the riparian and surrounded by a relatively undulating topography with a complex of hills (Figure 5).

The rafting tourism site can be accessed by concrete (Figure 6a) and asphalt roads (Figure 6b). Figure 6a shows that the access road around the start point has a width of $4 \mathrm{~m}$, and the road conditions are reinforced with concrete and generally relatively sloped. At the endpoint, the topography is relatively gentler with an elevation of $87 \mathrm{~m}$ AMSL, where the surrounding conditions are filled with dry fields and mixed gardens. This convenient land location is easily accessed, and it would be strategic to use it for the endpoints and logistic transfers. From the topographic analysis, this site would be suitable for collecting the rafting athletes and tourists. The access road in Figure $6 \mathrm{~b}$ illustrates the road conditions near the endpoint towards the starting point with a width of $3.5 \mathrm{~m}$ with mixed gardens on its sides, and, at several points, there are steep cliffs and v-shaped valleys.

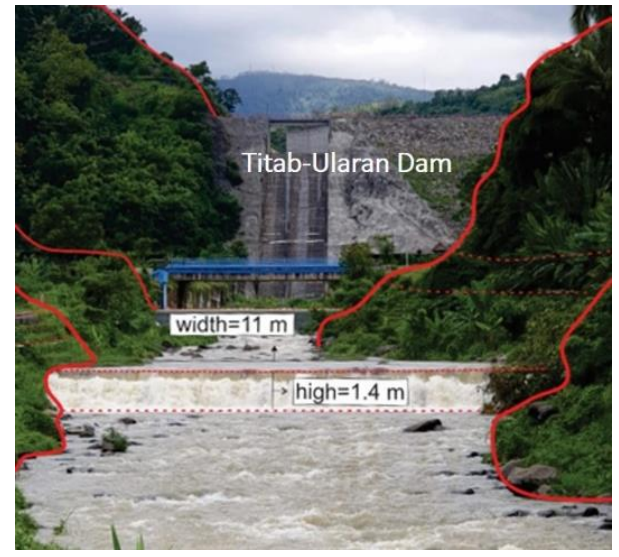

Figure 5. The starting point of Route SWISS in the UTM zone 50S, X: 273440, and Y: 9088781 (Courtesy: G.D. Jayanto, 2019)

The main contributing factor to the formation of whitewater is the characteristics of the river's cross-sections, namely the river slope, flow discharge, riverbed roughness, and the presence of meandering.

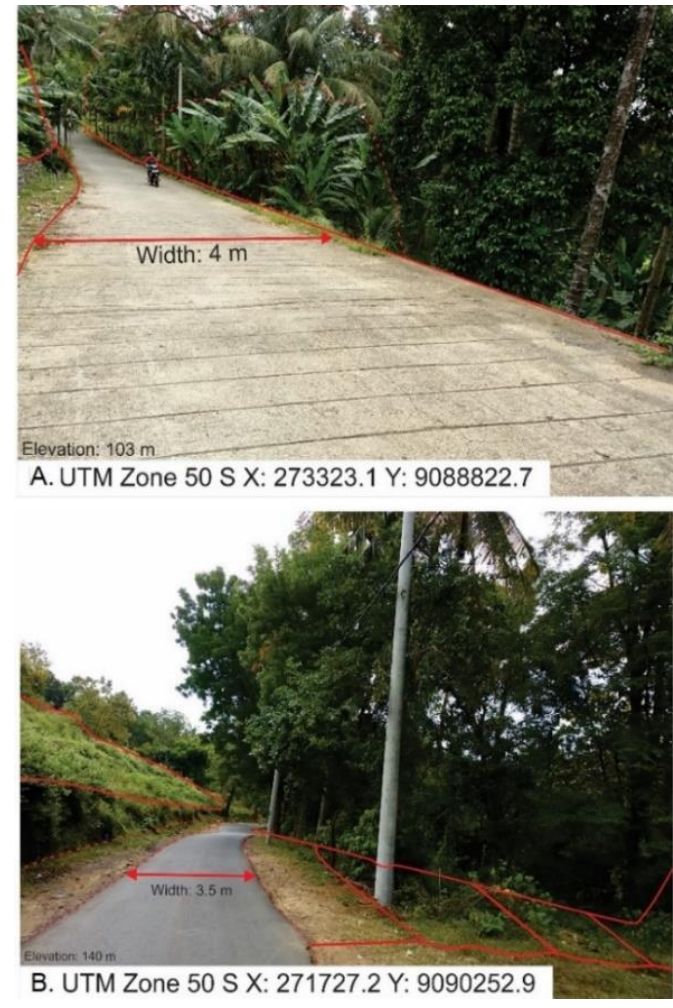

Figure 6. The road conditions towards the whitewater rafting tourism site (Courtesy: G.D. Jayanto, 2019)

\subsection{Channel and hydrological characteristics of route SWISS}

A river is physically characterized by its area, linearity, and relief. In this study, morphometry plays a pivotal role in identifying and understanding the potential and the threats of the Saba River. Route SWISS is downstream of the TitabUlaran Dam in Bali, which significantly affects the flow rate and water level along this route. During the dry seasons, rafting activity is not possible unless the floodgates are opened, and the resulting water flow can raise the river discharge in the suggested range of $20-200 \mathrm{~m}^{3} / \mathrm{s}$ [8, 26]. Since Route SWISS has a minimal discharge during dry seasons of $1.979 \mathrm{~m}^{3} / \mathrm{s}$, releasing the water from the dam would be necessary.

Based on the measurement results, the ideal discharge for rafting is $4.02 \mathrm{~m}^{3} / \mathrm{s}$, and the favorable water level is $0.4-0.7 \mathrm{~m}$. Table 2 shows the physical characteristics of Route SWISS in the Saba River. The meandering features and riverbed roughness are additional conditions for the formation of whitewater. Water turbulence in the Saba River occurs due to irregularities in riverbeds [27]. During the field survey, several meandering features were identified on Route SWISS, as meandering is one of the determinants in Manning's roughness coefficient.

Table 2 confirms that Route SWISS in the Saba River is an adequate and advisable segment for rafting tourism. The river slope of $14.2 \mathrm{~m} / \mathrm{km}$, along with the characteristics of the volcanic rocks in the river, shape the variations in the whitewater that are formed along this route. The ideal flow velocity for rafting is $0.32 \mathrm{~m} / \mathrm{s}$, and there is a directly proportional correlation between the flow velocity and the discharge. The slope area method showed that the maximum discharge along the route was $6.94 \mathrm{~m}^{3} / \mathrm{s}$ with a flow velocity of $4.6 \mathrm{~m} / \mathrm{s}$. Based on these conditions, there is a potential for flooding to occur, especially during the rainy season. 
Table 2. The physical parameters of the channel alongside the Route SWISS, Saba River, Bali

\begin{tabular}{cc}
\hline Parameters & Values \\
\hline Cross-sectional area & $3.9 \mathrm{~m}^{2}$ \\
Wet perimeter & $12.75 \mathrm{~m}$ \\
Cross-sectional width & $13 \mathrm{~m}$ \\
Manning's coefficient & 0.034 \\
Water level slope & 0.017 \\
Hydraulic radius & $0.31 \mathrm{~m}$ \\
Maximum discharge capacity & $6.94 \mathrm{~m}^{3} / \mathrm{s}$ \\
Measured discharge & $4.02 \mathrm{~m}^{3} / \mathrm{s}$ \\
River slope & $14.2 \mathrm{~m} / \mathrm{km}$ \\
Measured flow velocity & $0.32 \mathrm{~m} / \mathrm{s}$ \\
Maximum flow velocity & $4.96 \mathrm{~m} / \mathrm{s}$ \\
\hline
\end{tabular}

Source: field measurements (2019).

Consequently, the increased discharge and flow velocity may modify the whitewater features that are found on the route. In these situations, the water level and risk during the rafting activities will be elevated. Therefore, every river condition requires proper risk management.

\subsection{Rafting tourism potential of Saba River}

The river morphology, discharge, and water level determine the diversity of the whitewater. When the water level reaches 40-70 cm, the rapids create varying types of whitewater. Route SWISS has at least five specific features of whitewater, which have the potential to be tourist attractions. These features are dams, bottlenecks, eddies, mainstream, and undercut rocks.

In addition, the river fragments that have been selected in this research have great potential for water tourism in terms of their steepness. A more detailed topography analysis of the river channel fragments was identified through the field measurements and topographic map analysis, which included the land use around the rafting path, flow conditions, cliff conditions, channel conditions, rapids conditions, and rock distribution. These conditions are explained in Figure 7.

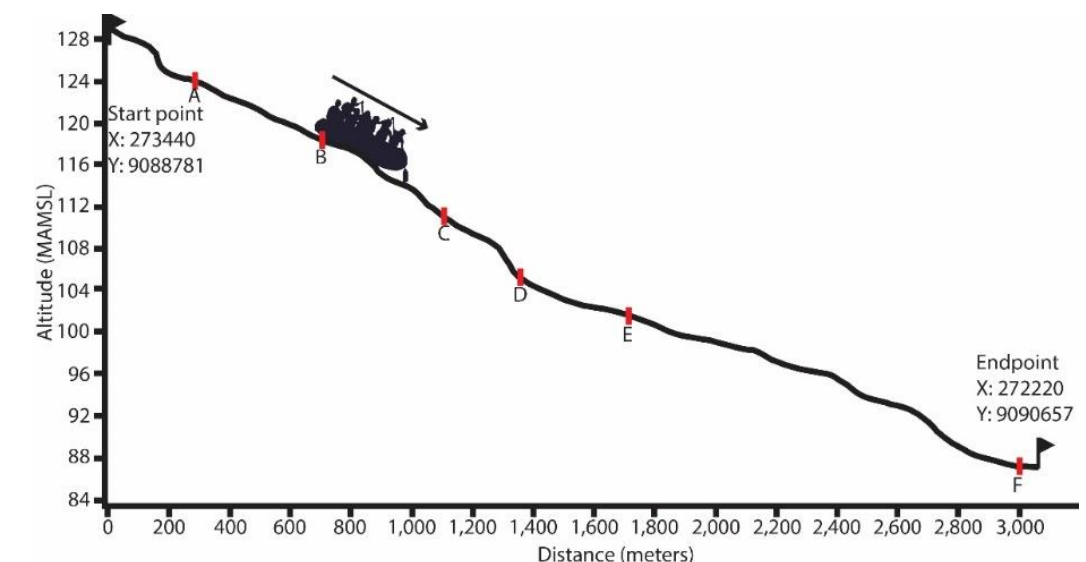

\begin{tabular}{|c|c|c|c|c|c|c|}
\hline & \multicolumn{6}{|c|}{ Distance (meters) } \\
\hline & $\stackrel{\text { A }}{\text { DAM } 1}$ & $\begin{array}{c}\text { B } \\
\text { Bottleneck }\end{array}$ & $\begin{array}{c}\mathrm{C} \\
\text { Undercut }\end{array}$ & $\begin{array}{c}\text { D } \\
\text { Mainstream } \\
\text { and Eddie }\end{array}$ & $\begin{array}{c}\text { E } \\
\text { DAM } 2\end{array}$ & $\begin{array}{c}\text { F } \\
\text { Stopper }\end{array}$ \\
\hline $\begin{array}{l}\text { Coordinates } \\
\text { (UTM 50S) }\end{array}$ & $\begin{array}{l}\text { X: } 273356 \\
\text { Y: } 9088977\end{array}$ & $\begin{array}{l}X: 273371 \\
\text { Y: } 9089336\end{array}$ & $\begin{array}{l}X: 273155 \\
\text { Y: } 9089378\end{array}$ & $\begin{array}{l}\text { X: } 273889 \\
\text { Y: } 9089695\end{array}$ & $\begin{array}{l}X: 272854 \\
\text { Y: } 9089378\end{array}$ & $\begin{array}{l}\text { X: } 272182 \\
\text { Y: } 9090497\end{array}$ \\
\hline $\begin{array}{l}\text { Flow } \\
\text { conditions }\end{array}$ & $\begin{array}{l}\text { Hydraulic } \\
\text { flow caused } \\
\text { by water } \\
\text { falling } \\
\text { vertically due } \\
\text { to the DAM } \\
\text { installation } \\
\text { forming a } \\
\text { circular flow } \\
\text { that consists } \\
\text { of backwash } \\
\text { and outwash } \\
\text { (turbulence } \\
\text { and rotational } \\
\text { current) }\end{array}$ & $\begin{array}{l}\text { The flow is } \\
\text { strong and } \\
\text { heavy due to } \\
\text { the } \\
\text { accumulation } \\
\text { of streams } \\
\text { resulting from } \\
\text { the narrowing } \\
\text { of the river } \\
\text { cross-section } \\
\text { (turbulence) }\end{array}$ & $\begin{array}{l}\text { The circular } \\
\text { current flow is } \\
\text { strong in the deep } \\
\text { water and } \\
\text { dangerous. The } \\
\text { stream rodes the } \\
\text { rock cliffs and } \\
\text { forms a vortex in } \\
\text { the depths of the } \\
\text { water at the edge } \\
\text { of the riverbank } \\
\text { and is associated } \\
\text { with meandering } \\
\text { (turbulence) }\end{array}$ & $\begin{array}{l}\text { The } \\
\text { mainstream } \\
\text { and heavy } \\
\text { currents are } \\
\text { concentrated } \\
\text { in the middle. } \\
\text { Eddie has } \\
\text { calm currents, } \\
\text { which occur } \\
\text { due to river } \\
\text { morphology } \\
\text { (turbulence) }\end{array}$ & $\begin{array}{l}\text { The hydraulic } \\
\text { flow is caused } \\
\text { by water } \\
\text { falling } \\
\text { vertically due } \\
\text { to the DAM } \\
\text { installation } \\
\text { forming a } \\
\text { circular flow } \\
\text { that consists } \\
\text { of backwash } \\
\text { and outwash } \\
\text { (turbulence } \\
\text { and rotational } \\
\text { current) }\end{array}$ & $\begin{array}{l}\text { The river } \\
\text { ornaments and } \\
\text { rocks that } \\
\text { appear on the } \\
\text { surface of the } \\
\text { water cause the } \\
\text { flow to } \\
\text { accumulate on } \\
\text { the right and left } \\
\text { side of the rock } \\
\text { and create the } \\
\text { appearance of } \\
\text { eddies } \\
\text { (turbulence) }\end{array}$ \\
\hline $\begin{array}{l}\text { Cliff } \\
\text { conditions }\end{array}$ & $\begin{array}{l}\text { Man-made } \\
\text { from stone on } \\
\text { the east side }\end{array}$ & $\begin{array}{l}\text { Steep rock } \\
\text { cliffs are } \\
\text { covered with } \\
\text { rooted plants } \\
\text { and are more } \\
\text { than } 5 \mathrm{~m} \text { in } \\
\text { height on the } \\
\text { east side }\end{array}$ & $\begin{array}{l}\text { Steep rock cliffs } \\
\text { are covered with } \\
\text { rooted plants and } \\
\text { are more than } 5 \mathrm{~m} \\
\text { in height on the } \\
\text { west side }\end{array}$ & - & $\begin{array}{l}\text { Man-made } \\
\text { from stone on } \\
\text { the east side }\end{array}$ & $\begin{array}{l}\text { The cliff is more } \\
\text { than } 5 \mathrm{~m} \text { in } \\
\text { height on the } \\
\text { west side }\end{array}$ \\
\hline $\begin{array}{l}\text { Channel } \\
\text { conditions }\end{array}$ & Uniform & $\begin{array}{l}\text { Uneven } \\
\text { channel } \\
\text { conditions }\end{array}$ & $\begin{array}{l}\text { Uniform, turn to } \\
\text { the right }\end{array}$ & $\begin{array}{l}\text { Uniform, turn } \\
\text { to the left }\end{array}$ & Uniform & Uniform \\
\hline $\begin{array}{l}\text { Rapids } \\
\text { conditions }\end{array}$ & $\begin{array}{l}\text { Strong hole } \\
\text { current }\end{array}$ & $\begin{array}{l}\text { Extremely } \\
\text { strong current } \\
\text { in the } \\
\text { bottleneck }\end{array}$ & Strong current & $\begin{array}{l}\text { Middle } \\
\text { current }\end{array}$ & $\begin{array}{l}\text { Strong hole } \\
\text { current }\end{array}$ & $\begin{array}{lr}\text { Low } & \text { current } \\
\text { speed } & \text { and } \\
\text { energy } & \end{array}$ \\
\hline $\begin{array}{l}\text { Rock } \\
\text { distribution }\end{array}$ & $\begin{array}{l}\text { Boulder-sized } \\
\text { rocks cover } \\
\text { less than } 30 \%\end{array}$ & $\begin{array}{l}\text { Boulder-sized } \\
\text { rocks are } \\
\text { spread across } \\
\text { the river } \\
\text { section }\end{array}$ & - & $\begin{array}{l}\text { Boulder-sized } \\
\text { rocks cover } \\
\text { less than } 30 \%\end{array}$ & - & $\begin{array}{l}\text { Few in number. } \\
\text { The big one is } \\
\text { called a stopper }\end{array}$ \\
\hline
\end{tabular}

Figure 7. The terrain and topography analysis 


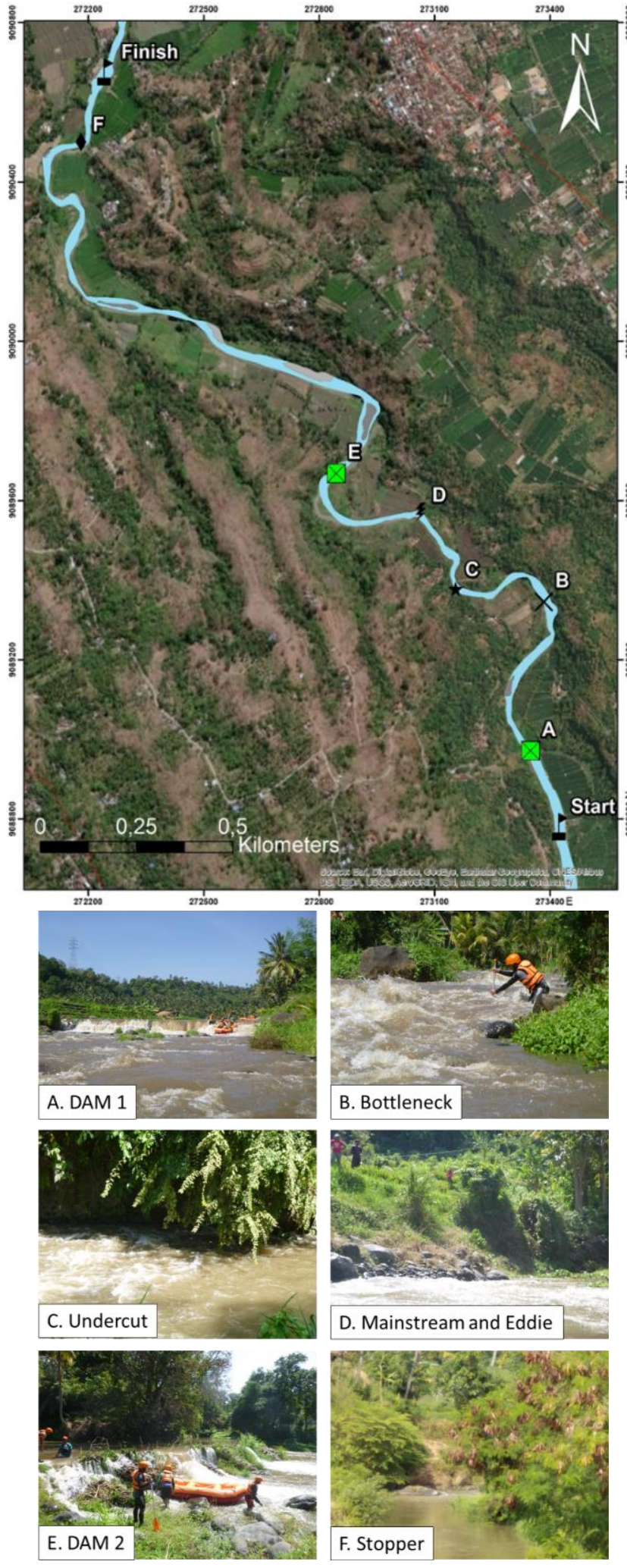

Figure 8. Spatial distribution of the whitewater alongside Route SWISS (Courtesy: G.D. Jayanto, 2019)

The first whitewater is formed due to the dam-like structures. It occurs when water pours over the edge of a submerged obstruction, such as a dam, which creates a whitewater (Figure 8a and 8e). The Titab-Ularan Dam is one of the attractions alongside Route SWISS. The water release causes flow turbulence and forms a unique whitewater [28]. Aside from the dams, the route also has undercut rocks that are found in the meandering segment that meets the rocky river cliffs. Undercuts accumulate energy and produce a strong current that can trap boats in a danger zone [29]. Bottlenecks are constrictions that form a rapid at a narrower channel. This narrowing accumulates flow discharge and velocity in one cross-section. When water is flowing into a narrower crosssection at the same discharge, it creates deeper water. Bottlenecks and undercuts (Figure $8 \mathrm{~b}$ and $8 \mathrm{c}$ ) are examples of obstacles that require special rafting techniques. The formation of mainstreams and eddies at the meanders offers another attraction alongside Route SWISS (Figure 8d). A mainstream is the product of rock configurations in the river channel, whereas eddies are calm spots that appear together with the mainstream [29]. Route SWISS also has eddies on the mainstream, as well as stoppers, which is a large stone that creates an obstacle or barrier (Figure 8f).

Based on the characteristics of the channel and the different features of whitewater, Route SWISS on Saba River may be categorized as grade $2-3$ rapids. Since Route SWISS in the Saba River has an ideal river slope and dominant waves among the other types of whitewater, rafting activities on this route are highly recommended for the people who have no experience of rafting, as well as for beginner whitewater rafters. Currently, Route SWISS is the only rafting trail that offers nature-based tourism at the Saba River. This route is 3 $\mathrm{km}$ in length and requires approximately 1.5-2 hours for completion. The rest area is located $1.15 \mathrm{~km}$ from the starting point.

\section{DISCUSSION}

\subsection{Risk management and awareness}

A risk is an unwanted event that results in physical and nonphysical losses. In rafting activities, risks can arise from natural and external factors. The internal risks include boat accidents, drifts, and changes in the terrain along the route, whereas the external risk is flooding. In an attempt to minimize the casualties in rafting tourism, the risk management needs to be established. Risk management can originate in the internalization of captains and tour service providers and the preparation of site accessibility and medical facilities.

This internalization requires training in first aid and other procedures to overcome any problems and difficulties that could arise during rafting. Proficiency in controlling the boats and familiarity with the terrain is fundamental knowledge that every captain or tour service provider must acquire. Meanwhile, determining access and available health services is essential in the rescue plan of victims as a form of emergency response.

The community along the route is welcoming the development of whitewater rafting tours on the Saba River. The friendly and open-minded village community offers an advantage to the development. Their support has been demonstrated by their active participation in establishing a tourism awareness group (Kelompok Sadar Wisata/POKDARWIS), which is named SWISS. This group consists of the local people who reside in the five villages that are traversed by Route SWISS and have been trained to run whitewater rafting tours as operators, tour guides, and administrators.

During the field measurements, this group showed enthusiasm for developing whitewater rafting tours in the Saba River. However, preparing to deal with every obstacle and the captain's skills still need improvement to keep the tourists on a safe route during the rafting activities. This development 
needs to include basic rescue training and technical training in controlling the boats while dealing with a multitude of whitewater forms. Alongside Route SWISS, there are several accident-prone points (capsized boats), especially at the undercut rocks, bottlenecks, and dams. For this reason, the captain needs to clearly understand how to properly row and position the boats to prevent the chance of capsizing. The captain's comprehension and proficiency to take action when a boat capsizes during the rafting activities is the primary emergency response to the inevitable risks in rafting tourism.

\subsection{Flood mitigation measures}

In 2011, the government of the Buleleng Regency and the Indonesian Ministry for Public Works and Human Settlements constructed the biggest dam in Bali Island, the Titab-Ularan Dam, in the middle of the Saba sub watershed as a flood mitigation measure. The dam controls the flow in the river channel in both the dry and rainy seasons, and, consequently, provides a sufficient water supply to the surroundings. The flood events upstream and downstream of the dam can be anticipated by analyzing the morphometric and hydrological characteristics of the river. The risk management plan needs to be continued with a detailed mapping of all forms of the potential risks of Route SWISS. Based on the results of the morphometry analysis and peak discharge measurements, Saba River can be identified as a river that is prone to flooding. The maximum peak discharge of $11.89 \mathrm{~m}^{3} / \mathrm{s}$ exceeds the fullest capacity of the channel, which is $6.94 \mathrm{~m}^{3} / \mathrm{s}$ (Table 3 ). Furthermore, the recent flood events in 2018 and 2019 in the Saba River confirm this finding.

Table 3. The flood threats alongside Route SWISS.

\begin{tabular}{cc}
\hline Parameters & Values \\
\hline Time to peak & 13.15 hours \\
Time to base & 24.1 hours \\
Peak discharge & $11.89 \mathrm{~m}^{3} / \mathrm{s}$ \\
Maximum capacity & $6.94 \mathrm{~m}^{3} / \mathrm{s}$ \\
\hline
\end{tabular}

\section{CONCLUSIONS}

The topography at the study site tends to be complex, as the mixture of hills and steep v-shaped valleys and the development of the valleys are not yet advanced. This natural condition is supportive of adventure activities, such as rafting. Channel characteristics with attractive variations can be developed as a spot for rafting sports; namely, the presence of eddie's current, undercut spots, straight tracks with variations in the distribution of rocks, rapids, and the surrounding beautiful scenery, such as the paddy fields and plantations. Based on the results of the field observations, the path and access to the start point and endpoint have potential for further development. An adequate road width and good road conditions are supportive of the logistics and participant transportation without many significant obstacles.

The method that was used for the morphometric analysis used the DEM data from the integration of the ALOS PALSAR satellite imagery and topographic maps in the GIS vector, which are considered an appropriate method format. The same method can be applied to several other regions that have a similar potential in Indonesia.

The characteristics of the channel and hydrology in the Saba River are suitable for rafting tourism. Saba River has grade 2
3 rapids, with several features of whitewater, including undercut rocks, bottlenecks, mainstreams, eddies, stoppers, and waves.

The development of a rafting tourism site requires an adequately planned risk management that incorporates the skills of the boat captains and the members of the tourism awareness group (POKDARWIS), as well as improved road access and mapping of the nearest health services. The advantages of this research is the detailed findings on the Saba river fragment that can be developed as a water tourism location. Furthermore, water tourism development can also have a significant impact on improving the lives of the local communities along the rafting tourism route. Accordingly, further detailed research on the physical characteristics of whitewater and its relation to the river hydraulics, risks, and risk management techniques in rafting tourism in the Saba River will be necessary.

\section{ACKNOWLEDGMENTS}

This paper has been written as part of collaborative research between the Faculty of Geography Universitas Gadjah Mada and the government of the Buleleng Regency in Bali. The authors thank SWISS POKDARWIS, Gede Eka Budi Darmawan, and Made Agus Wijaya for their help in the field. The authors dedicate this article to Prof. Sunarto, as well as to Dionisius Prasetyo, who died recently; you meant a lot to us and thank you for always being genuine. Finally, the authors would also like to thank the anonymous reviewers for their helpful comments on this paper.

\section{REFERENCES}

[1] Carolli, M., Zolezzi, G., Geneletti, D., Siviglia, A., Carolli, F., Cainelli, O. (2017). Modelling white-water rafting suitability in a hydropower regulated alpine river. Science of the Total Environment, 579: 1035-1049. https://doi.org/10.1016/j.scitotenv.2016.11.049

[2] Mutaqin, B.W., Marfai, M.A., Helmi, M., Rindarjono, M.G., Windayati, R., Sunarto. (2020). Spatio-temporal mapping of ecotourism activities in Buleleng Conservation Zone: A methodological review. IOP Conference Series: Earth Environmental Sciences, 451: 012095 . https://doi.org/10.1088/1755$1315 / 451 / 1 / 012095$

[3] Mutaqin, B.W. (2017). Shoreline changes analysis in Kuwaru Coastal Area, Yogyakarta, Indonesia: An application of the digital shoreline analysis system (DSAS). International Journal of Sustainable Development and Planning, 12(7): 1203-1214. https://doi.org/10.2495/SDP-V12-N7-1203-1214

[4] Marfai, M.A., Ahmada, B., Mutaqin, B.W., Windayati, R. (2020). Dive resort mapping and network analysis: Water resources management in Pemuteran Coastal Area, Bali Island, Indonesia. Geographia Technica, 15(2): 106116. http://doi.org/10.21163/GT_2020.152.11

[5] Russi, D., ten Brink, P., Farmer, A., Badura, T., Coates, D., Förster, J., Kumar, R., Davidson, N. (2013). The Economics of Ecosystems and Biodiversity for Water and Wetlands. IEEP, London and Brussels, Ramsar Secretariat, Gland.

[6] Korua, L., Kurniawan, J., Ruswino, A., Taufan, M. (1997). Panduan Dasar Arung Jeram. Jakarta: FAJI. 82p 
[7] Mokarram, M., Sathyamoorthy, D. (2015). Morphometric analysis of hydrological behavior of north fars watershed, Iran. European Journal of Geography, 6(4): $88-106$.

[8] Hasanah, M., Sugiyanta, I.G., Miswar, D. (2017). Karakteristik Jalur Arung jeram di Way Sekampung Provinsi Lampung Tahun 2016. Jurnal Penelitian Geografi, 5(9).

[9] Rahman, R., Rindam, M. (2017). River morphometry analysis and its capacity to introduce tourism attraction in Sedim River, Kedah. GEOGRAFI, 5(2): 127-137.

[10] Macerinskiene, A. (2010). Determination criteria for national water tourism routes. WIT Transactions on Ecology and the Environment, 139: 145-158. https://doi.org/10.2495/ST100131

[11] Youssef, A.M., Pradhan, B., Hassan, A.M. (2011). Flash flood risk estimation along the St. Katherine road, southern Sinai, Egypt using GIS-based morphometry and satellite imagery. Environmental Earth Sciences, 62(3): 611-623. https://doi.org/10.1007/s12665-010-0551-1

[12] Waikar, M.L., Nilawar, A.P. (2014). Morphometric analysis of a drainage basin using geographical information system: A case study. International Journal of Multidisciplinary and Current Research, 2: 179-184.

[13] Angillieri, M.Y.E., Fernandez, O.M. (2017). Morphometric analysis of river basins using GIS and remote sensing of an Andean section of Route 150, Argentina. A comparison between manual and automated delineation of basins. Revista Mexicana de Ciencias Geologicas, 34(2): 150-156. https://doi.org/10.22201/cgeo.20072902e.2017.2.482

[14] Ramírez, J.A. (2000). Prediction and modeling of flood hydrology and hydraulics. Chapter 11 of Inland Flood Hazards: Human, Riparian, and Aquatic Communities. Eds. Ellen Wohl; Cambridge University Press.

[15] The Office of Watershed Management and Social Forestry Assistance. (2013). Peraturan Direktur Jenderal Bina Pengelolaan Daerah Aliran Sungai Dan Perhutanan Sosial No. P. 3/V-Set/2013 Tentang Pedoman Identifikasi Karakteristik Daerah Aliran Sungai. Kementerian Kehutanan Republik Indonesia. http://bpdashl-cimanukcitanduy.com/wpcontent/uploads/2016/05/PDIRJEN-NO.3-TH-2013TTG-KARATERISTIK-DAS.pdf.

[16] Pareta, K., Pareta, U. (2012). Quantitative geomorphological analysis of a watershed of Ravi River Basin. H.P. India. International Journal of Remote Sensing and GIS, 1(1): 41-56.

[17] Romshoo, S.A., Bhat, S.A., Rashid, I. (2012). Geoinformatics for assessing the morphometric control on the hydrological response at the watershed scale in the Upper Indus Basin. Journal of Earth System Science, 121(3): 659-686. https://doi.org/10.1007/s12040-0120192-8

[18] Sangle, A.S., Yannawar, P.L. (2014). Morphometric analysis of watershed using GIS and RS: A review. International Journal of Engineering Research \& Technology (IJERT), 3(11): 599-602

[19] Mutaqin, B.W., Lavigne, F., Sudrajat, Y., Handayani, L., Lahitte, P., Virmoux, C., Hiden, Hadmoko, D.S., Komorowski, J.C., Hananto, N., Wassmer, P., Hartono, Boillot-Airaksinen, K. (2019). Landscape evolution on the eastern part of Lombok (Indonesia) related to the $1257 \mathrm{CE}$ eruption of the Samalas Volcano.
Geomorphology,

327:

$338-350$.

https://doi.org/10.1016/j.geomorph.2018.11.010

[20] Chow, V.T. (1959). Open channel hydraulics. McGrawHill, New York.

[21] Herschy, R. (1993). The velocity-area method. Flow measurement and instrumentation, 4(1): 7-10. https://doi.org/10.1016/0955-5986(93)90004-3

[22] Berhitu, P.T., Mulyono, R.M. (2014). Analisa Karakteristik Hidrologi dan Model Dinamik Sungai Way Ruhu pada Kawasan Pesisir Desa Galala Kota Ambon. Jurnal Teknologi, 11(2): 2045-2053.

[23] Henderson, F.M. (1966). Open channel flow. New York: Macmillan.

[24] Griffiths, G. and McKerchar, A. (2015). Estimation of low flow statistics at unmonitored sites by correlation of concurrent base flow gaugings. Journal of Hydrology (NZ), 54(2): 147-152.

[25] Tirasatayapitak, A., Chaiyasain, C., Beeton, R.J.S. (2014). Can hybrid tourism be sustainable? White water rafting in Songpraek Village, Thailand. Asia Pacific Journal of Tourism Research, 20(2): 210-222. https://doi.org/10.1080/10941665.2013.877045

[26] McGinnis, W. (1975). Whitewater Rafting. New York: The New York Times Book Co.

[27] Marlina, N., Hudori., Hafidh, R. (2017). Pengaruh kekasaran saluran dan suhu air sungai pada parameter kualitas air cod, Tss di sungai winongo menggunakan software qual2kw. Jurnal Sains dan Teknologi Lingkungan, $\quad 9(2)$ : 122-133. https://doi.org/10.20885/jstl.vol9.iss2.art6

[28] Nikora, V. (2005). Flow turbulence over mobile gravelbed: Spectral scaling and coherent structures. Acta Geophysica Polonica, 53(4): 539-552.

[29] Das, V.K., Roy, S., Barman, K., Debnath, K., Chaudhuri, S., Mazumder, C.S. (2019). Investigations on the undercutting processes of the cohesive river bank. Engineering Geology, 252: 110-124. https://doi.org/10.1016/j.enggeo.2019.03.004

\section{NOMENCLATURE}

Q flow discharge $\left(\mathrm{m}^{3} / \mathrm{s}\right)$

A wet cross-sectional area $\left(\mathrm{m}^{2}\right)$

$\mathrm{V}$ flow velocity $(\mathrm{m} / \mathrm{s})$

d water depth (m)

w wet cross-sectional width (m)

a current meter constant $\mathrm{N}^{0} .1$

b current meter constant $\mathrm{N}^{0} .2$

$\mathrm{n}$ number of rotations

$n \quad$ Manning's roughness coefficient

$\mathrm{R} \quad$ hydraulic radius $(\mathrm{m})$

$\mathrm{S}$ the slope of the free-water surface $(\mathrm{m} / \mathrm{m})$

$\mathrm{n}_{0} \quad$ the base value of $\mathrm{n}$ for a straight, uniform, smooth channel in natural materials

$\mathrm{n}_{1} \quad$ correction factor for the effect of surface irregularities

$\mathrm{n}_{2} \quad$ value for variations in the shape and size of the channel cross-section

$\mathrm{n}_{3} \quad$ value for obstructions

$\mathrm{n}_{4} \quad$ value for vegetation and flow conditions

$\mathrm{m}$ correction factor for meandering of the channel 